\title{
Quantitative Evaluation of the Reactivity of Alkylating Agents
}

\author{
Nicholas Bodor*a, James J. Kaminskib, S. D. Worleyc, and Steven H. Gerson ${ }^{\mathrm{a}}$ \\ Department of Medicinal Chemistry, College of Pharmacy, J. Hillis Miller Health Center, \\ University of Florida, Gainesville, Florida 32610; Schering Corporation, Bloomfield, N. J. \\ 07003; and Department of Chemistry, Auburn University, Auburn, Alabama 36830
}

Z. Naturforsch. 35 b, 758-763 (1980); received February 4, 1980

Alkylating Agents, Soft Drugs, NMR Spectra, Competitive Alkylation, Soft Quaternary Salts

A sensitive and reproducible method for quantitative evaluation of the relative reactivities of alkylating agents was developed, based on competitve alkylation. The method is superior to the known colorimetric methods. The reactivities of the agents could also be correlated with the ${ }^{13} \mathrm{C}$ chemical shifts of the $\alpha$-methylene. The method was successfully applied for the ranking of "soft" alkylating agents of low reactivity.

It was recently found that "soft" alkylating $\mathrm{R}_{1}$ agents of the type $\mathrm{R}-\mathrm{COOCH}-\mathrm{Y}(\mathbf{1})(\mathrm{Y}=\mathrm{Cl}$ or $\mathrm{Br})$ have anticancer activity [1]. (Soft drugs are defined as active therapeutic agents which undergo predictable and controllable metabolism after they achieve their therapeutic role [2]. Thus, "soft" alkylating agents of the type $\mathbf{1}$ are subject to ester cleavage (enzymic or chemical), according to the equation:

$$
\begin{gathered}
\mathrm{R}_{1} \\
\stackrel{1}{\mathrm{R}-\mathrm{COOCH}-\mathrm{Y}+\mathrm{H}_{2} \mathrm{O}} \\
\mathrm{R}-\mathrm{COOH}+\mathrm{R}_{1} \mathrm{CHO}+\mathrm{HY}
\end{gathered}
$$

The "soft" terms, thus reflect the easily biodegradable characteristics of these compounds, opposite to the conventional "hard" (non-biodegradable) alkylating agents.)

In order to establish a relation between the activity and structure of these agents, a method to evaluate quantitatively their relative alkylating reactivities was developed, which is compared to the method of Epstein et al. [3]. The Epstein procedure is based on the spectrophotometric analysis of the colored product 2 formed from 4-(4-nitrobenzyl)pyridine (NBP) and alkylating (or arylating agent) (A-X), by reacting them in methyl ethyl ketone, followed by addition of a base (deprotonation of the benzylic methylene):

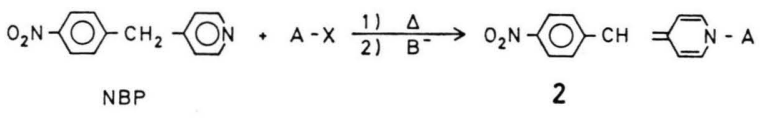

a University of Florida, b Schering Corporation, c Auburn University.

* Reprint requests to Dr. N. Bodor. 0340-5087/80/0600-0758/\$01.00/0
An alternate method [4] used acetophenone as a solvent and $180^{\circ}$ as the reaction temperature, and a large number of alkylating agents were thus assayed, including N-mustards [5].

It is clear that NBP is a weak base. Thus, under the conditions suggested [3], no reaction was observed with the soft alkylating agents (1) having also very low reactivity. It was found that the expected colored products can be obtained if $\mathbf{l}$ is heated at $70{ }^{\circ} \mathrm{C}$ for one hour with a large excess of the neat NBP. Using different amounts of $\mathbf{1}$, a plot of the concentration $v s$ absorbance of 2 resulted in straight lines of different slopes, apparently depending on the reactivity of $\mathbf{1}$. For characterization of the alkylating reactivities, the M 301 values suggested by Epstein [3] were determined (M 301 is the moles of the alkylating agent required to produce a colored solution having 0.301 absorbance at $565 \mathrm{~nm}$ ). The values obtained for a series of closely related soft alkylating agents are listed in Table I. It can be seen that although methyl iodide was predicted to be more reactive than $1 \mathrm{a}-\mathbf{l} \mathbf{h}$, the structurally related compounds cannot be differentiated with sufficient accuracy. It is difficult to believe that the bromo derivative $\mathbf{l} \mathbf{h}$ is less reactive than $\mathbf{1 a}$.

The drastic conditions of the alternate method [4] were not investigated. It is difficult to expect that closely related compounds will show reliable differences by reacting them at $180^{\circ} \mathrm{C}$ for $3.5 \mathrm{~min}$ [4]. It was also found that the intensity of the color of 2 is time dependent, contributing to the inaccuracy.

A new method [1] for quantitative evaluation of relative alkylating reactivities was then investigated in detail. The method is based on a competitive alkylation of a selected tertiary amine (for example, 3 -acetoxy-quinuclidine (3)) by a 1:1 molar mixture 
Table I. Moles of alkylating agents (1) required to produce colored solution of 2 having 0.301 absorbance $\left(\mathrm{R}_{1}=\mathrm{H}\right.$ in all cases $)$.

\begin{tabular}{llll}
\hline Nr. ${ }^{\mathrm{a}}$ & $\mathrm{R}$ & $\mathrm{Y}$ & $\mathrm{M} 301\left(\mathrm{M} \times 10^{6}\right)^{\mathrm{b}}$ \\
\hline $\mathbf{1 a}$ & $\left(\mathrm{CH}_{3}\right)_{3} \mathrm{C}$ & $\mathrm{Cl}$ & $0.826 \pm 0.05$ \\
$\mathbf{1} \mathbf{b}$ & $\mathrm{CH}_{3}\left(\mathrm{CH}_{2}\right)_{2}$ & $\mathrm{Cl}$ & $0.890 \pm 0.05$ \\
$\mathbf{1 c}$ & $\mathrm{CH}_{3}\left(\mathrm{CH}_{2}\right)_{4}$ & $\mathrm{Cl}$ & $1.05 \pm 0.05$ \\
$\mathbf{1} ; \mathbf{d}$ & $\mathrm{CH}_{3}\left(\mathrm{CH}_{2}\right)_{10}$ & $\mathrm{Cl}$ & $1.43 \pm 0.05$ \\
$\mathbf{1 e}$ & $\mathrm{CH}_{3}\left(\mathrm{CH}_{2}\right)_{12}$ & $\mathrm{Cl}$ & $1.07 \pm 0.05$ \\
$\mathbf{1} \mathbf{f}$ & $\mathrm{CH}_{3}\left(\mathrm{CH}_{2}\right)_{14}$ & $\mathrm{Cl}$ & $1.17 \pm 0.05$ \\
$\mathbf{1 g}$ & $\mathrm{C}_{6} \mathrm{H}_{5}$ & $\mathrm{Cl}$ & $0.998 \pm 0.05$ \\
$\mathbf{1} \mathbf{h}$ & $\mathrm{C}_{6} \mathrm{H}_{5}$ & $\mathrm{Br}$ & $1.06 \pm 0.05$ \\
Methyl iodide & & & $0.714 \pm 0.05$ \\
\hline
\end{tabular}

a $\mathbf{1 a}$ is commercially available, compounds $\mathbf{1 b}-\mathbf{1 h}$ were synthesized previously [1]. The benzoates $\mathbf{1 g}$ and $1 \mathrm{~h}$ were obtained according to ref. [8].

b An accuracy of 5 percent [3] was considered.

c Methyl iodide was included for comparison.

of the compound studied and a standard alkylating agent, followed by the direct analysis of the composition of the reaction mixture:

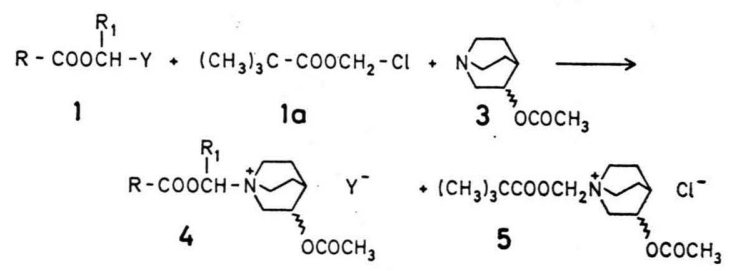

The tertiary amine 3 was chosen because of its structural rigidity, while the easily available chloromethyl pivalate (1a) was selected as the standard agent. Using a 1:1:1 molar mixture of $1: 1 \mathrm{a}: 3$, the ratio of the amounts of the products $4 / 5$ quantitatively reflects the relative alkylating reactivity (RAR).

The present work reports studies on the sensitivity of the competitive method, by comparing reactivities of the structurally closely related series of substituted benzoylmethyl halides:

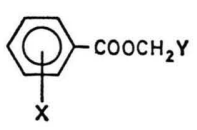

\begin{tabular}{lll}
\hline $\mathrm{Nr}$. & $\mathrm{X}$ & $\mathrm{Y}$ \\
\hline $\mathbf{1} \mathbf{g}$ & $\mathrm{H}$ & $\mathrm{Cl}$ \\
$\mathbf{1} \mathbf{h}$ & $\mathrm{H}$ & $\mathrm{Br}$ \\
$\mathbf{1} \mathbf{i}$ & $p-\mathrm{CH}_{3} \mathrm{O}$ & $\mathrm{Cl}$ \\
$\mathbf{1} \mathbf{j}$ & $p-\mathrm{CH}_{3}$ & $\mathrm{Cl}$ \\
$\mathbf{1 ~ k}$ & $m-\mathrm{Br}$ & $\mathrm{Cl}$ \\
$\mathbf{1}$ & $m-\mathrm{NO}_{2}$ & $\mathrm{Cl}$ \\
$\mathbf{1} \mathbf{m}$ & $p-\mathrm{Cl}$ & $\mathrm{Cl}$ \\
$\mathbf{1} \mathbf{n}$ & $p-\mathrm{Br}$ & $\mathrm{Cl}$ \\
$\mathbf{1 ~ o}$ & $p-\mathrm{NO}_{2}$ & $\mathrm{Cl}$ \\
\hline
\end{tabular}

The reaction mixtures of $4 \mathrm{~g}-\mathbf{4 0}$ is 5 were analyzed by NMR, comparing the sharp singlet resonance signals corresponding to the $\geqslant \mathrm{N}^{+}-\mathrm{CH}_{2}-\mathrm{O}-\mathrm{O}-\mathrm{C}-\mathrm{R}$ methylene, at expanded sweep width. The ${ }^{1} \mathrm{H}$ and ${ }^{13} \mathrm{C}$ chemical shifts of the methylene group in $\mathbf{1 ~ a - 1 ~ 0 ~}$ and the ${ }^{1} \mathrm{H}$ shifts of the methylene protons in the corresponding soft quaternary salts $\mathbf{4}$ are shown in Table II.

Table II. ${ }^{1} \mathrm{H}$ and ${ }^{13} \mathrm{C}$ chemical shifts of the methylene group of selected chloromethyl carboxylatesa $(\mathbf{3})$ and the corresponding soft quaternary salts ${ }^{b}(4)$.

\begin{tabular}{|c|c|c|c|}
\hline $\begin{array}{l}\text { Compound } \\
\text { Nr. }\end{array}$ & $\begin{array}{l}\text { Chemical s } \\
\delta^{1} \mathrm{H}[\mathrm{ppm}]\end{array}$ & $\begin{array}{l}\text { shift in } 1 \\
\delta^{13} \mathrm{C}[\mathrm{ppm}]\end{array}$ & $\begin{array}{l}\text { Chemical shift in } 4 \\
\delta^{1} \mathrm{H}[\mathrm{ppm}]\end{array}$ \\
\hline $\mathbf{a}$ & 5.70 & & $5.23(5)^{\mathrm{c}}$ \\
\hline g & 5.97 & 69.40 & 5.47 \\
\hline i & 5.90 & 69.38 & 5.50 \\
\hline $\mathbf{j}$ & 5.90 & 69.33 & 5.50 \\
\hline $\mathbf{k}$ & 6.00 & 69.44 & 5.57 \\
\hline 1 & 6.03 & 69.69 & 5.63 \\
\hline $\mathbf{m}$ & 5.93 & 69.41 & 5.57 \\
\hline $\mathbf{n}$ & 5.93 & 69.35 & 5.57 \\
\hline $\mathbf{0}$ & 6.00 & 69.63 & 5.70 \\
\hline
\end{tabular}

a Chemical shifts measured in $\mathrm{CDCl}_{3}$ solutions.

b Chemical shifts measured in $\mathrm{D}_{2} \mathrm{O}$ - $\mathrm{d}^{6}$-acetone.

c Chloromethyl pivalate (1 a) and the corresponding salt 5 included for comparison.

It can be seen that the ${ }^{1} \mathrm{H}$ shifts are not too sensitive to the ring substituents, but the ${ }^{13} \mathrm{C}$ shifts show the expected trend.

The ${ }^{1} \mathrm{H}$ chemical shifts of $\mathbf{4 g} \mathbf{- 4 0}$ are sufficiently separated from that of 5 , which was selected as the standard. The results of the competitive alkylation are shown in Table III.

The percent product composition values are the average of two separate experiments found to be reproducible with \pm 0.5 percent. Taking the reactivity of the unsubstituted $\mathbf{l g}$ as unity, the RAR values were normalized and listed as $\mathrm{pX} / \mathrm{pH}$. Plotting $\mathrm{pX} / \mathrm{pH}$ values against the corresponding substituent constants $\left(\sigma^{\circ}\right)$ [6] a good correlation was obtained, as shown in Fig. 1.

Benzyl chloride (6) and the unhindered soft alkylating agent chloromethyl hexanoate (7) were also included in Table III, for comparison. As expected, 6 is much more reactive than the soft agents 1g-10. Finally, as expected, the bromo derivative $1 \mathrm{~h}$ is about 18 times more reactive than the corresponding chloro compound $\mathbf{l g}$. 
Table III. Relative alkylating reactivities (RAR) of substituted halomethyl benzoates.

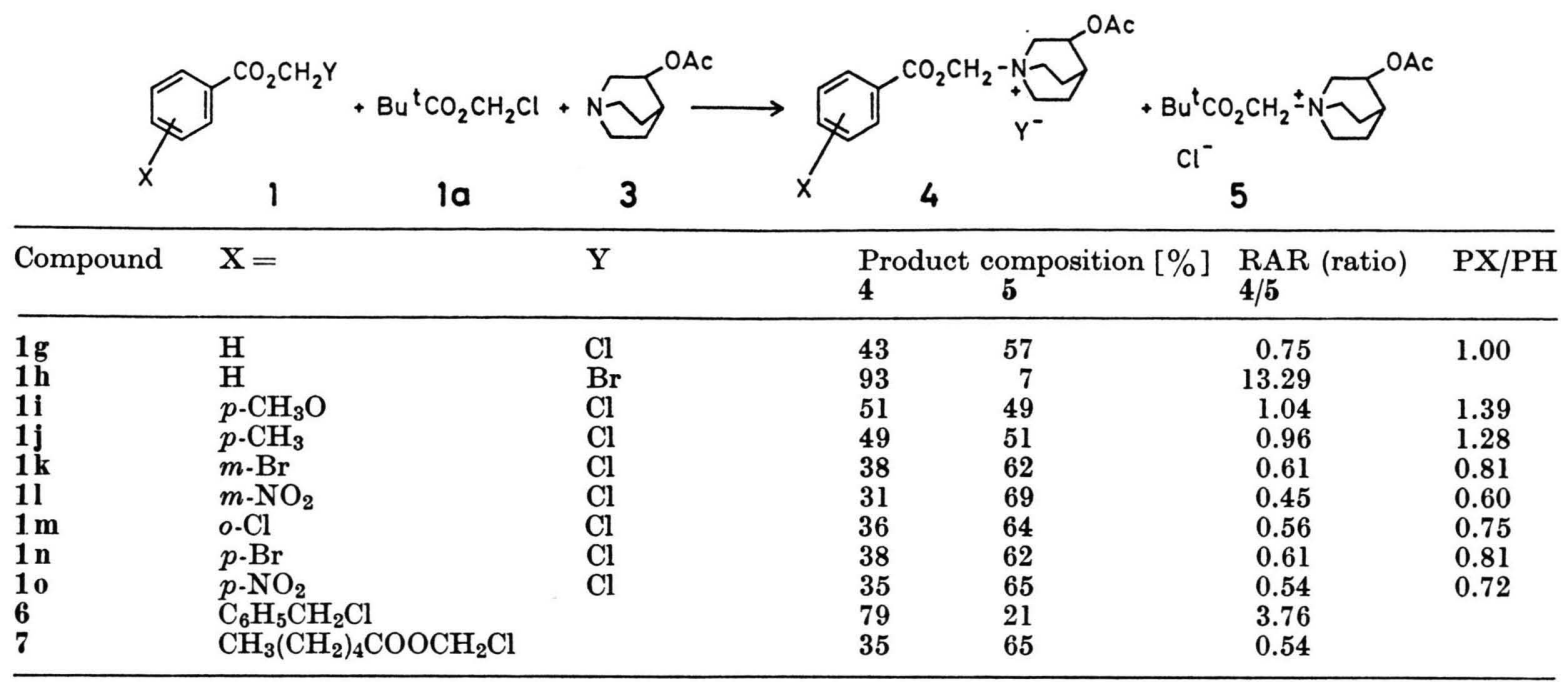

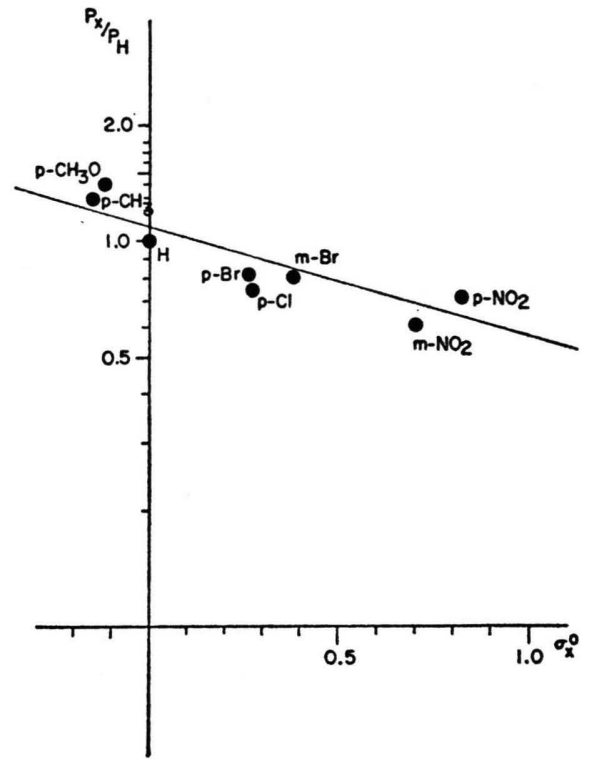

Fig. 1. Plot of relative reactivities $(\mathrm{pX} / \mathrm{pH})$ of substituted chloromethyl benzoates $v s \sigma^{\circ}$. Slope -0.32 ; $\mathbf{r}=0.90$.

The relative differences in the ${ }^{13} \mathrm{C}$ chemical shifts $\left(\Delta \delta^{13} \mathrm{C}=\delta^{13} \mathrm{C}_{\mathbf{X}}-\delta^{13} \mathrm{C}_{\mathrm{H}}\right)$ in the series $\mathbf{1 h}-\mathbf{l o}$ were also plotted against $\sigma^{\circ}$, obtaining a fairly good correlation.

In conclusion, the competitive alkylation provides a sensitive and reliable method for predicting quantitatively the alkylating reactivity of a wide variety of agents. By choosing proper standards, a full scale of reactivity of the known agents can be

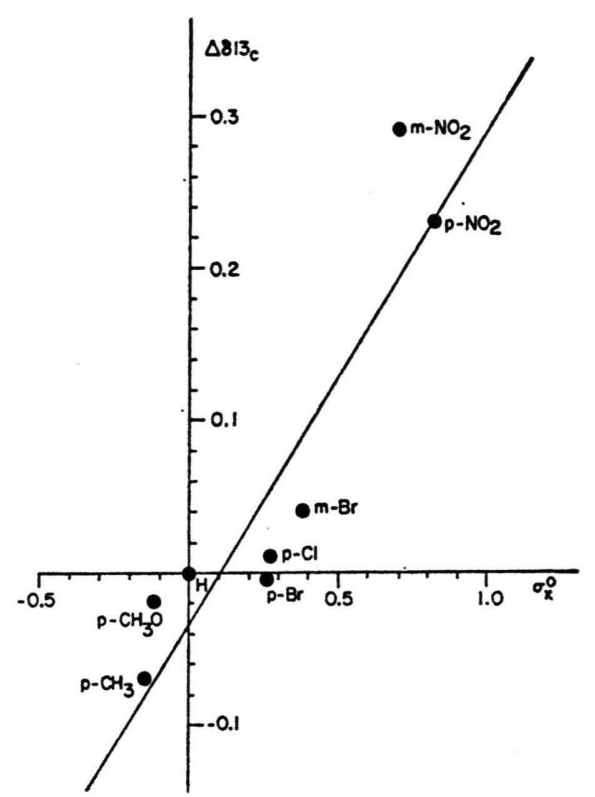

Fig. 2. Plot of ${ }^{13} \mathrm{C}$ chemical shifts of the methylene carbon in substituted chloromethyl benzoates $v s \sigma^{\circ}$. Slope $=0.33 ; \mathrm{r}=0.89$.

developed, since the method is certainly not limited to the soft alkylating agents studied. Conventional alkylating agents, N-mustards, etc. could quantitatively be compared by this method. As the ratio of the products formed under the conditions used (1:1:1 starting molar ratios and consuming all the amine) is not simply proportional with $\mathrm{k}_{1} / \mathrm{k}_{2}$ [7], it is possible to achieve better selectivity while using 
the amine in large excess or not allowing the reaction to be completed. In a relatively short time, the ratio of the products formed is proportional with $k_{1} / k_{2}$, as the starting alkylating agent's concentrations is the same. If the "short time" restriction does not hold, $\mathrm{k}_{1} / \mathrm{k}_{2}$ is proportional with the ratio of the logarithm of the products.

\section{Experimental}

\section{Synthesis}

3-Acetoxyquinuclidine (5) was prepared by acetylation of 3-quinuclidinol. The product was purified by vaccum distillation. M.p. $34-36{ }^{\circ} \mathrm{C}$; b. p. $76-78{ }^{\circ} \mathrm{C}$ $(0.8 \mathrm{~mm})$.

Benzyl chloride (6) and chloromethyl pivalate (1 a) were obtained from Aldrich Chemical Company.

Chloromethyl benzoate $(\mathbf{1} \mathbf{h})$ was prepared from benzoyl chloride and paraformaldehyde using the method described by Ulich and Adams [8], b.p. $84-85{ }^{\circ} \mathrm{C}(1.2 \mathrm{~mm})$ [Lit. [8] b. p. 114-115 ${ }^{\circ} \mathrm{C}(8 \mathrm{~mm})$ ] IR (neat) 3060, 2990, 1730, 1590, 1490, 1450, 1340, $1300,1250,1080,800$ and $720 \mathrm{~cm}^{-1}$; PMR $\left(\mathrm{CDCl}_{3}\right)$ $\delta$ 7.0-8.2 (m, 5H) and $5.97(\mathrm{~s}, 2 \mathrm{H}) \mathrm{ppm}$. Bromomethyl benzoate $(\mathbf{l g})$ was obtained analogously, using benzoyl bromide, b.p. $62-65^{\circ} \mathrm{C}(0.3 \mathrm{~mm})$ [Lit. [8] $135-137^{\circ} \mathrm{C}(19 \mathrm{~mm})$ ].

Using the procedure described for the preparation of $\mathbf{l h}$, the following $\alpha$-chloromethyl benzoates were prepared:

Chloromethyl p-methoxybenzoate (1i): b.p. 119 to $121{ }^{\circ} \mathrm{C}(0.5 \mathrm{~mm})$, IR (neat) $2980,2915,1720,1595$, $1500,1430,1330,1245,1165,1070,845,770$ and $710 \mathrm{~cm}^{-1}$; PMR $\left(\mathrm{CDCl}_{3}\right) \delta 6.7-8.2\left(\mathrm{AA}^{\prime} \mathrm{BB}^{\prime}, 4 \mathrm{H}\right)$, $5.90(\mathrm{~s}, 2 \mathrm{H})$ and $3.78(\mathrm{~s}, 3 \mathrm{H}) \mathrm{ppm}$.

Analysis for $\mathrm{C}_{9} \mathrm{H}_{9} \mathrm{ClO}_{3}$

$\begin{array}{lll}\text { Calcd } & \text { C 53.88 } & \text { H 4.52, } \\ \text { Found } & \text { C 54.14 } & \text { H 4.72. }\end{array}$

Chloromethyl p-methylbenzoate $(\mathbf{1} \mathrm{j})$ : b.p. $92-94{ }^{\circ} \mathrm{C}$ (1 mm), IR (neat) 2990, 2960, 1730, 1600, 1435, $1340,1255,1175,1080,1020,840,750$ and $720 \mathrm{~cm}^{-1}$; PMR (CDCl $\left.{ }_{3}\right) \delta 7.0-8.1\left(\mathrm{AA}^{\prime} \mathrm{BB}^{\prime}, 4 \mathrm{H}\right), 5.90(\mathrm{~s}, 2 \mathrm{H})$ and $2.33(\mathrm{~s}, 3 \mathrm{H}) \mathrm{ppm}$.

$\begin{array}{ccc}\text { Analysis for } \mathrm{C}_{9} \mathrm{H}_{9} \mathrm{ClO}_{2} & \\ \text { Calcd } & \mathrm{C} 58.55 & \mathrm{H} \\ \text { 4.91, } \\ \text { Found } & \mathrm{C} \mathrm{58.94} & \mathrm{H} \mathrm{5.27.}\end{array}$

Chloromethyl m-bromobenzoate (1k): b.p. 110 to $113{ }^{\circ} \mathrm{C}(0.8 \mathrm{~mm})$, IR (neat) $3030,2990,1730,1560$, $1440,1340,1240,1090,1000,750$ and $720 \mathrm{~cm}^{-1}$; PMR $\left(\mathrm{CDCl}_{3}\right) \delta 7.1-8.4(\mathrm{~m}, 4 \mathrm{H})$ and $6.00(\mathrm{~s}, 2 \mathrm{H})$ ppm.

Analysis for $\mathrm{C}_{8} \mathrm{H}_{6} \mathrm{BrClO}_{2}$

Calcd C 38.51 H 2.42,

Found C 38.67 H 2.57.
Chloromethyl m-nitrobenzoate $(1 \mathrm{l})$ : m.p. $42-44{ }^{\circ} \mathrm{C}$, b. p. $154-156^{\circ} \mathrm{C}(0.8 \mathrm{~mm})$; IR (neat) 3040,1740 , $1610,1420,1350,1250,1110,1000,775$ and $725 \mathrm{~cm}^{-1}$; PMR $\left(\mathrm{CDCl}_{3}\right) \delta 7.6-8.6(\mathrm{~m}, 4 \mathrm{H})$ and $6.03(\mathrm{~s}, 2 \mathrm{H})$ ppm.

Analysis for $\mathrm{C}_{8} \mathrm{H}_{6} \mathrm{ClNO}_{4}$

$\begin{array}{llll}\text { Calcd } & \text { C 44.56 } & \text { H 2.81 } & \text { N 6.50, } \\ \text { Found } & \text { C 44.96 } & \text { H 3.18 } & \text { N 6.05. }\end{array}$

Chloromethyl p-chlorobenzoate $(1 \mathrm{~m})$ : b.p. $88-90{ }^{\circ} \mathrm{C}$ $(0.3 \mathrm{~mm})$, IR (neat) $2990,1725,1580,1250,1080$, $1010,845,755$ and $710 \mathrm{~cm}^{-1}$; PMR $\left(\mathrm{CDCl}_{3}\right) \delta 7.2$ to $8.0\left(\mathrm{AA}^{\prime} \mathrm{BB}^{\prime}, 4 \mathrm{H}\right)$ and $5.93(\mathrm{~s}, 2 \mathrm{H}) \mathrm{ppm}$.

Analysis for $\mathrm{C}_{8} \mathrm{H}_{6} \mathrm{Cl}_{2} \mathrm{O}_{2}$

Calcd C 46.86 H 2.95,

Found C 47.11 H 3.18.

Chloromethyl p-bromobenzoate (1n): b.p. 108 to $110^{\circ} \mathrm{C}(0.3 \mathrm{~mm})$, IR (neat) $2990,1730,1580,1395$, $1255,1085,1010,850,760$ and $720 \mathrm{~cm}^{-1}$; PMR $\left(\mathrm{CDCl}_{3}\right) \delta 7.3-8.0\left(\mathrm{AA}^{\prime} \mathrm{BB}^{\prime}, 4 \mathrm{H}\right)$ and $5.93(\mathrm{~s}, 2 \mathrm{H})$ ppm.

Analysis for $\mathrm{C}_{8} \mathrm{H}_{6} \mathrm{BrClO}_{2}$

$\begin{array}{lll}\text { Calcd } & \text { C 38.51 } & \text { H 2.42, } \\ \text { Found } & \text { C 38.75 } & \text { H 2.56. }\end{array}$

Chloromethyl p-nitrobenzoate (1 o): m.p. $83-87^{\circ} \mathrm{C}$, chromatographed on magnesium silicate, carbon tetrachloride; IR (KBr) 3060, 1730, 1520, 1340, $1260,1090,1010,990,860,735$ and $720 \mathrm{~cm}^{-1}$; PMR $\left(\mathrm{CDCl}_{3}\right) \delta 8.3(\mathrm{~s}, 4 \mathrm{H})$ and $6.00(\mathrm{~s}, 2 \mathrm{H}) \mathrm{ppm}$.

Analysis for $\mathrm{C}_{8} \mathrm{H}_{6} \mathrm{ClNO}_{4}$

Calcd C 44.56 H $2.81 \quad \mathrm{~N} 6.50$,

Found C 44.85 H 3.04 N 6.87.

The high resolution mass measurements of the molecular ions $\left(\mathrm{M}^{+}\right)$for the substituted chloromethyl benzoates are given in Table IV.

Table IV. High resolution mass measurements of the molecular ion ( $\left.\mathbf{M}^{+\cdot}\right)$ for substituted chloromethyl benzoates.

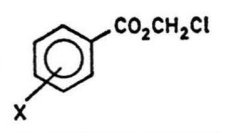

\begin{tabular}{|c|c|c|c|c|}
\hline Nr. & $\mathrm{X}=$ & caled for & & observed \\
\hline & $\mathrm{H}$ & $\mathrm{C}_{8} \mathrm{H}_{7} \mathrm{ClO}_{2}$ & 1341 & 1290 \\
\hline $1 \mathrm{i}$ & $p-\mathrm{CH}_{3} \mathrm{O}$ & & & 137 \\
\hline & & & 184 & 184.03119 \\
\hline 11 & $m-\mathrm{Br}$ & $\mathrm{C}_{8} \mathrm{H}_{6} \mathrm{BrClO}_{2}$ & 247.923 & 247.92542 \\
\hline 11 & $m \cdot \mathrm{NO}_{2}$ & $\mathrm{C}_{8} \mathrm{H}_{6} \mathrm{ClNO}_{4}$ & 214 . & 215.00008 \\
\hline $1 \mathrm{~m}$ & $p$-Cl & $\mathrm{C}_{8} \mathrm{H}_{6} \mathrm{Cl}_{2} \mathrm{O}_{2}$ & 203.9 & 203.98231 \\
\hline $1 \mathrm{n}$ & & $\mathrm{C}_{8} \mathrm{H}_{6} \mathrm{BrClO}_{2}$ & 247 & 247.92093 \\
\hline 10 & $p$-NO & $\mathrm{C}_{8} \mathrm{H}_{6} \mathrm{ClNO}_{4}$ & 214.99848 & 214.99843 \\
\hline
\end{tabular}

\section{Determination of the $M 301$ values}

To different quantities of alkylating agents $1 \mathbf{a}-\mathbf{1 ~ h}$ in dry pear-shaped flasks were added $300 \mathrm{mg}$ of 4-(4-nitrobenzyl) pyridine. The flask was connected 
to a condenser and the mixture heated at $70 \pm 0.10^{\circ} \mathrm{C}$ for $1 \mathrm{~h}$, using a preheated oil bath, then cooled for one minute in an ice-water bath. Acetone $(16 \mathrm{ml})$ was added through the condenser, followed by $1 \mathrm{ml}$ of 50 percent triethylamine in acetone. The purple color which appears immediately was read within two minutes, at $565 \mathrm{~nm}$. All concentrations were measured against distilled water. The standard curves for each agent were constructed using 4-5 different concentrations. The M301 values were obtained from the standard curves.

\section{Determination of relative alkylating reactivities (RAR)}

To an acetonitrile solution $(9 \mathrm{ml})$ containing $158.8 \mathrm{mg} \quad(1.26 \mathrm{mmol})$ benzyl chloride (6) and $189.0 \mathrm{mg}$ (1.26 mmol) chloromethyl pivalate (1a) was added $212.9 \mathrm{mg}(1.26 \mathrm{mmol}) 3$-acetoxyquinuclidine (5) dissolved in $6 \mathrm{ml}$ acetonitrile. The solution was heated at $70 \pm 0.1^{\circ} \mathrm{C}$ for $1 \mathrm{~h}$. The acetonitrile was removed under reduced pressure and the residue obtained was dried in vacuo over anhydrous calcium sulfate. The residue was dissolved in $\mathrm{D}_{2} \mathrm{O} \cdot \mathrm{d}^{6}$ acetone $(1: 2 \mathrm{v} / \mathrm{v})$. The composition of the isolated product mixture was determined by multiple integration (5 determinations) of an appropriate resonance signal of the products at expanded sweep widths $\left(250 \mathrm{H}_{3}\right)$. Examples are given in Fig. 3 .

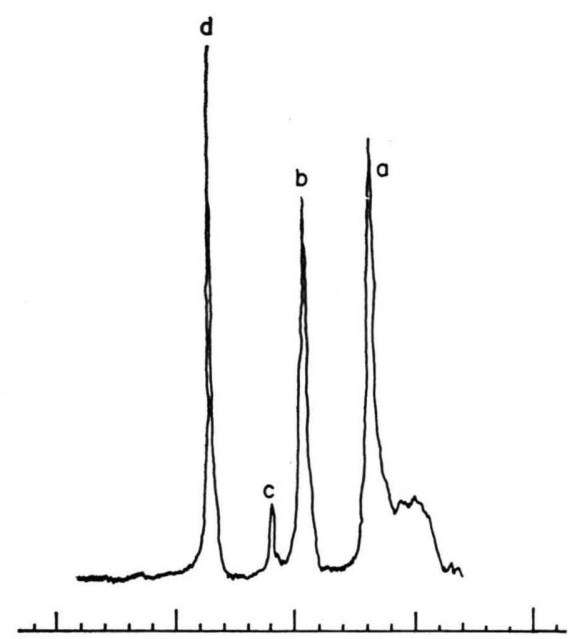

Fig. 3. The PMR spectrum of the reaction mixture of $1 \mathbf{h}: 1 \mathrm{a}: 3=1: 1: 1$. The methylene peaks : $\mathrm{a}-\mathbf{5} ; \mathrm{b}-\mathbf{4 h}$; c $-1 \mathbf{a}$ and $\mathrm{d}-\mathbf{1} \mathrm{h}$

Using the procedure described for determining the selectivity of benzyl chloride $(6)$ relative to chloromethyl pivalate (1 a) in reaction with 3 acetoxyquinuclidine (5), the haloalkyl carboxylates $\mathbf{l g}-\mathbf{1 0}$ were also investigated. The corresponding soft quaternary salts were all isolated and identified, as follows:
1-p-Methoxybenzolyloxymethyl-3-acetoxyquinuclidinium chloride $(4 \mathrm{i})$ : m.p. $185-187{ }^{\circ} \mathrm{C}$ (dec): IR (KBr) 3020, 2990, 1725, 1705, 1590, 1505, 1250, $1170,1105,1020$ and $770 \mathrm{~cm}^{-1}$; PMR $\left(\mathrm{D}_{2} \mathrm{O}\right) \delta 7.0$ to $8.2\left(\mathrm{AA}^{\prime} \mathrm{BB}^{\prime}, 4 \mathrm{H}\right), 5.5(\mathrm{~s}, 2 \mathrm{H}), 3.97(\mathrm{~s}, 3 \mathrm{H}), 3.4-4.4$ $(6 \mathrm{H}), 2.3(\mathrm{~s}, 3 \mathrm{H})$ and $2.0-3.0(6 \mathrm{H}) \mathrm{ppm}$.

$$
\begin{array}{ccccc}
\text { Analysis for } \mathrm{C}_{18} \mathrm{H}_{24} \mathrm{ClNO}_{5} & \\
\text { Calcd } & \mathrm{C} 58.45 & \mathrm{H} 6.54 & \mathrm{~N} 3.79, \\
\text { Found } & \mathrm{C} 58.00 & \mathrm{H} 6.37 & \mathrm{~N} 3.55 .
\end{array}
$$

p-Methylbenzoyloxymethyl-3-acetoxyquinuclidinium chloride $(4 \mathrm{j})$ : m. p. $201-204{ }^{\circ} \mathrm{C}$ (dec); IR (KBr) 3000 , $2980,1720,1610,1370,1280,1250,1120$ and $760 \mathrm{~cm}^{-1}$; PMR $\left(\mathrm{D}_{2} \mathrm{O}\right) \delta 7.2-8.2\left(\mathrm{AA}^{\prime} \mathrm{BB}^{\prime}, 4 \mathrm{H}\right), 5.50$ $(\mathrm{s}, 2 \mathrm{H}), 3.4-4.2(6 \mathrm{H}), 2.4(\mathrm{~s}, 3 \mathrm{H}), 2.0-2.8(6 \mathrm{H})$ and $2.2(\mathrm{~s}, 3 \mathrm{H}) \mathrm{ppm}$.

$$
\begin{array}{cccc}
\text { Analysis for } & \mathrm{C}_{18} \mathrm{H}_{24} \mathrm{ClNO}_{4} \\
\text { Calcd } & \mathrm{C} 61.10 & \mathrm{H} 6.84 & \mathrm{~N} 3.96, \\
\text { Found } & \mathrm{C} 61.19 & \mathrm{H} 6.72 & \mathrm{~N} 3.68 .
\end{array}
$$

m-Bromobenzoyloxymethyl-3-acetoxyquinuclidinium chloride (4k): m.p. $207-209{ }^{\circ} \mathrm{C}$ (dec); IR (KBr) $2990,2920,1725,1715,1560,1280,1250,1230,1085$, 1020 and $745 \mathrm{~cm}^{-1}$; PMR $\left(\mathrm{D}_{2} \mathrm{O}\right) \delta 7.4-8.4(4 \mathrm{H}), 5.57$ $(\mathrm{s}, 2 \mathrm{H}), 3.5-4.4(6 \mathrm{H}), 2.0-3.0(6 \mathrm{H})$ and $2.2(\mathrm{~s}, 3 \mathrm{H})$ ppm.

$$
\begin{array}{cccc}
\text { Analysis for } & \mathrm{C}_{17} \mathrm{H}_{21} \mathrm{BrClNO}_{4} & \\
\text { Calcd } & \mathrm{C} 48.76 & \mathrm{H} 5.06 & \mathrm{~N} 3.35, \\
\text { Found } & \mathrm{C} 48.58 & \mathrm{H} 5.03 & \mathrm{~N} 3.25 .
\end{array}
$$

m-Nitrobenzoyloxymethyl-3-acetoxyquinuclidinium chloride (4l): m.p. $176-179^{\circ} \mathrm{C}$ (dec); IR (KBr) 3040 , $2980,1730,1605,1420,1345,1260,1230,1120,1040$ and $720 \mathrm{~cm}^{-1}$; PMR $\left(\mathrm{D}_{2} \mathrm{O}\right) \delta 7.6-8.8(4 \mathrm{H}), 5.63$ $(\mathrm{s}, 2 \mathrm{H}), 3.4-4.0(6 \mathrm{H}), 1.8-3.1(6 \mathrm{H})$ and $2.2(\mathrm{~s}, 3 \mathrm{H})$ ppm.

$$
\begin{array}{cccc}
\text { Analysis for } & \mathrm{C}_{17} \mathrm{H}_{21} \mathrm{ClN}_{2} \mathrm{O}_{6} & \\
\text { Calcd } & \mathrm{C} 53.06 & \mathrm{H} 5.50 & \mathrm{~N} 7.28, \\
\text { Found } & \mathrm{C} 53.40 & \mathrm{H} 5.72 & \mathrm{~N} 7.01 .
\end{array}
$$

p-Chlorobenzoyloxymethyl-3-acetoxyquinuclidinium chloride $(4 \mathrm{~m})$ : m.p. $193-196{ }^{\circ} \mathrm{C}$ (dec); IR (KBr) $3040,2990,1725,1590,1490,1400,1370,1250,1100$, $1015,855,760$ and $690 \mathrm{~cm}^{-1}$; PMR $\left(\mathrm{D}_{2} \mathrm{O}\right) \delta 7.4-8.3$ $\left(\mathrm{AA}^{\prime} \mathrm{BB}^{\prime}, 4 \mathrm{H}\right), 5.57(\mathrm{~s}, 2 \mathrm{H}), 3.4-4.2(6 \mathrm{H}), 2.0-3.0$ $(6 \mathrm{H})$ and $2.2(\mathrm{~s}, 3 \mathrm{H}) \mathrm{ppm}$.

\section{Analysis for $\mathrm{C}_{17} \mathrm{H}_{21} \mathrm{Cl}_{2} \mathrm{NO}_{4}$ \\ Calcd C 54.55 H 5.66 N 3.74, \\ Found C 54.50 H 5.51 N 3.54.}

p-Bromobenzoyloxymethyl-3-acetoxyquinuclidinium chloride (4n): m.p. $198-201{ }^{\circ} \mathrm{C}$ (dec); IR (KBr) $2980,1720,1575,1255,1230,1100,1005,840$ and $750 \mathrm{~cm}^{-1}$; PMR $\left(\mathrm{D}_{2} \mathrm{O}\right) \delta 7.6-8.2\left(\mathrm{AA}^{\prime} \mathrm{BB}^{\prime}, 4 \mathrm{H}\right), 5.57$ $(\mathrm{s}, 2 \mathrm{H}), 3.4-4.2(6 \mathrm{H}), 2.0-3.0(6 \mathrm{H})$, and $2.2(\mathrm{~s}, 3 \mathrm{H})$ ppm. 
Analysis for $\mathrm{C}_{17} \mathrm{H}_{21} \mathrm{BrClNO}_{4}$

Calcd C 48.76 H $5.06 \quad \mathrm{~N} 3.35$,

Found C 48.36 H 5.05 N 3.24.

p-Nitrobenzoyloxymethyl-3-acetoxyquinuclidinium

chloride (40): m.p. $179-182{ }^{\circ} \mathrm{C}$ (dec); IR (KBr)

$2990,1720,1510,1340,1260,1230,1100,1020$,

840 and $710 \mathrm{~cm}^{-1}$; PMR $\left(\mathrm{D}_{2} \mathrm{O}\right) \delta 8.4(\mathrm{~s}, 4 \mathrm{H}), 5.70$ $(\mathrm{s}, 2 \mathrm{H}), 3.4-4.2(6 \mathrm{H}), 2.0-3.0(6 \mathrm{H})$ and $2.3(\mathrm{~s}, 3 \mathrm{H})$ ppm.

Analysis for $\mathrm{C}_{17} \mathrm{H}_{21} \mathrm{ClN}_{2} \mathrm{O}_{6}$

Calcd C 53.06 H 5.50 N 7.28,

Found C 53.19 H 5.72 N 7.48.

[1] N. Bodor and J. J. Kaminski, J. Med. Chem. 23, 566 (1980).

[2] N. Bodor, J. Med. Chem. 23, 469 (1980).

[3] J. Epstein, R. W. Rosenthal, and R. J. Ess, Anal. Chem. 27, 1435 (1955).

[4] E. Sawicki, D. F. Bender, T. R. Hauser, R. M. Wilson (Jr.), and J. E. Meeker, Anal. Chem. 35, 1479 (1963).
[5] O. M. Friedman and E. Boger, Anal. Chem. 33, 906 (1961).

[6] R. W. Taft, J. Phys. Chem. 64, 1805 (1960).

[7] K. J. Laidler, Chemical Kinetics, McGraw Hill Co., New York 1965.

[8] L. H. Ulich and R. Adams, J. Am. Chem. Soc. 43, 660 (1921). 